\title{
The Use of Internet Reporting for Small Business
}

\author{
Kumi Heenetigala and Anona Armstrong \\ Victoria University, Australia
}

\begin{abstract}
Small business is receiving increasing attention from government because of its potential to drive innovation and economic growth in the wake of the global financial crisis. The lean governance structures in small business mean that decisions are quickly made and implemented. Multiple decisions can modify production processes, produce a new product, apply new marketing methods or tap new markets. These decisions are deeply connected with issues of technological capability and incentives to invest in new innovations. However, many small businesses are likely to have limited access to skills, and lack information about markets and technology. Knowledge about these issues in small businesses is often provided by their accountants. The purpose of this study was to determine how accountants could assist small businesses to make better use of emerging web based technologies to communicate with their accountants. The research was supported by a major grant from the National Institute of Accountants. This paper reports research in which twenty two accountants and their clients were interviewed to determine the potential adoption and use of web based information and communications technology to provide immediate on-going communication between small businesses and their accountants. It is the first article to investigate the support for and barriers to the use of interactive technology to promote small business via the web. The research questions addressed in this paper were: What uses do small businesses currently made of ICT? What are some of the new opportunities offered by ICT to accountants? What are the barriers to the use of new technology? What are the benefits to accountants and their small business clients?
\end{abstract}

\section{Keywords}

ICT adoption, accountants, small business, e-business

\section{Introduction}

The most significant driver of innovation at the present time is information and communications technology (ICT). In small business, the major uses made of ICT technology are in the management of a business and responding to compliance with government regulation. Small businesses may lack specialist knowledge. Therefore when there is a need to comply with regulation and/ or legislation, a key option available to small businesses is to use consultants. The most common consultant that small businesses engage is the accountant. In most cases an accountant can assist a business to comply with record keeping required by law and occasionally may be required to provide advice such as

Copyright (C) 2009 Victoria University. This document has been published as part of the Journal of Business Systems, Governance and Ethics in both online and print formats. Educational and non-profit institutions are granted a nonexclusive licence to utilise this document in whole or in part for personal or classroom use without fee, provided that correct attribution and citation are made and this copyright statement is reproduced. Any other usage is prohibited without the express permission of the publisher. recommendations on computer systems (Burgess and Hill 2004). Accountants play a significant role in many small businesses, not only in compiling the end of year figures but also in day-to-day operations, risk management and monitoring cash flows and performance.

The purpose of this study was to determine how accountants could assist small businesses to make better use of emerging 
technologies based on the web to communicate with their accountants.

It is common to hear small business referred to as the "engine room" of the economy because, of its potential to drive innovation and economic growth ${ }^{24}$. There are approximately 1.93 million active small businesses in Australia. They represent ninety six percent of all businesses. Small businesses employ over 5 million people, accounting for around fifty one percent of private sector employment. Small businesses contribute over one third of Australia's total GDP.

Not only is small business a source of economic activity but the sector is expanding rapidly. The past two decades saw a four-fold increase in the number of small and medium enterprises from 577,100 in the financial year of 1983-84 to more than two million in 2007 (see Figure 1). One can equally say that one person out of ten in Australia owns his/her own business ${ }^{25}$. SMEs accounts for about $99.71 \%$ of all private sector entities, while large firms never exceeded $1 \%$ of aggregate firm numbers during $1983-2007^{26}$.

In general, corporate governance is concerned with the structures and processes for decision-making, accountability, control and behaviour at the top of organisations. Numerous guidelines and standards for good governance have been developed. For the most part they are directed at 'big' corporations. Decision making refers to all those matters which affect the vision, performance and long term sustainability of an organisation. IT is one of the most significant expenditure items and consideration of the IT strategy is a major issue for most boards. The E-environment offered by integrative technology offers SMEs a new way to manage their businesses and probably impacts on the sustainability of small businesses in general.

The lean governance structures in small business mean that decisions can be quickly made and implemented. At a time of recovery from the global financial crisis (GFC) small business activity offers a major safety net for employment. Research has found that small business make a disproportionate contribution to employment (Birch 1987; Gallagher and Miller 1991).

Because of its importance and potential for further growth, the Australian government is examining ways of supporting small business and reducing the burden of compliance with regulation. One way of doing this is to determine if there are other less intrusive and innovative ways of ensuring compliance. A significant driver of innovation at the present time is information and communications technology (ICT).

A variety of stakeholders can benefit from the use of internet reporting facilities. SME owners will have access to ongoing updated reports of business performance. They may also be more efficient if data entry can be made only once for the variety of regulatory bodies and their accountants. Regulatory bodies such as ASIC and the Taxation Department and a host of industry regulators could have information automatically collected and aggregated in regular standard reports. Accountants could have a continuous reporting regime from their clients in which figures are automatically updated and forwarded from their clients at regular intervals (instead of the one major 'dump' at the end of the financial year). Too often, a SME will only become aware of cash flow or other problems when their accountant finally gets to look at their accounts. Therefore The theoretical contributions of this project relate to the governance of SMEs (Francis and Armstrong 2006) and the development of new approaches to the adoption of integrative adaptive systems for businesses in an E-environment.

Although there is considerable research into the barriers to small business growth (Doern 2009) there is very little research on the use, and barriers to the use, of communications technology in this context. The purpose of this study was to fill this gap by determining how accountants could work with small businesses to make better use of emerging technologies based on the web. This article discusses the characteristics of small business, describes the methodology and the conceptual framework and the results of the study.

\footnotetext{
24 Senator Hon Nick Sherry Assistant Treasurer 2009 The importance of small business to the Australian economy. Speech to the Small Business Forum. Hobart, Tasmania 21 November 2009

25 The last Census shows the Australia population is about 22 million.

26 Australia Bureau of Statistics (2007), Counts of Australia Businesses, including Entries and Exits. Cat. no. 8165.0. Canberra.
} 


\section{Characteristics of Small Business}

There are various definitions of small business but the one adopted here is that of the corporations law (Australian Corporations and Securities Legislation 2009). A company is classified as a small business if it satisfies two of three following conditions:

- Consolidated revenue for the financial year is less than \$25 million.

- The value of gross assets at the end of the financial year is less than $\$ 12.5$ million.

- The company has less than 50 employees at the end of the financial year.

The Australian Bureau of Statistics also has a lesser category that it calls micro, which has less than 5 employees.

Two thirds of small businesses with less than 20 employees are home-based, and more than half of them do not have any staff at all; an estimated $10-30 \%$ of all business owners are in their second or third time to start a new business; and almost $10 \%$ of small business operators run two or more businesses concurrently.

The characteristics that are identified with small business are:

- They have a relatively small share of their marketplace;

- They are privately, often family owned;

- They are managed by owners, often owner/managers;

- They are independent, in the sense that they are not part of a larger enterprise;

- They may have resource constraints.

Family owned businesses are well represented in small businesses and the philosophy of the family or owner/manager will have a major effect on business generally and particularly in relation to the adoption and use of new technology (Breen, Sciulli et al. 2003).

Due to the particular characteristics of small businesses, the way they deal with corporate governance issues are different form larger firms. For example small businesses may be owner/manager operated, family businesses or even partnerships. Navarro and Anson (2009) provide empirical evidence of family corporate governance structures. Boards are smaller than non-family firms. They are biased towards insiders, and have fewer non-executive directors and board committees. Similar results were reported in relation to small corporations in an Australian study (Clarke and Kettner 2009 in press). Family companies have longer serving chairmen, often the owner. In Asia, more than two thirds are controlled by a single shareholder (Navarro and Anson 2009). This latter point means that the traditional explanation for the introduction of modern governance practices, agency theory, may have limited application for these kinds of organisations, as the interests of managers and owners are aligned.

Many small firms occupy niche markets and offer a specialized service or product. Storey (Fillis Ian and Wagner Beverly 2005) identifies three areas where small firms differ from large firms: (1) uncertainty: the small business has a limited customer base and products; (2) Innovation: refers to the niche role of some firms but also refers to the extremely fast rate at which some firms can grow. Small firms tend to be more likely to introduce essentially new innovations and less committed to existing practices and products; (3) Evolution: small firms are more likely to evolve and change.

Due to the above characteristics, small businesses face various barriers to IT implementation. Prior studies report that the barriers to implementation of IT management systems for small businesses are: cost, lack of time to devote to the implementation and maintenance of IT, lack of knowledge combined with difficulty in finding useful and impartial advice, lack of use of external consultants and vendors, lack of understanding of the benefits that IT can provide, how to measure those benefits and lack of formal planning, the cost of new infrastructure, the time to implement solutions, and uncertain returns on investment (Burgess 2002) and lack of time and effort put into planning where the business is heading (Burgess and Schauder 2003).

Financial management is also a significant issue for small business, due to the volatility associated with situations such as cash and profit position, reliance on short term debt and need for financial 
information. Large number of small businesses fails in the first five year of business. The reasons for the failure are: no formal reporting requirements, no proper debt management, cash-flow problems, insufficient reliable information to measure their performance (Watson and Everett 1996), high rate of interest demanded by the banks. Eighty percent of all new businesses fails due to undercapitalization (Festervand and Forrest 1991). Hence, the financial services offered by accountants can make a significant contribution to the success of a small business.

The main issues emerging from consideration of small business characteristics is that their use and adoption of innovations, such as new ways of communicating with their accountants, may be influenced by lack of time, expertise, and financial resources, and access to IT resources (equipment, manpower, skills, time) (Burgess and Schauder 2003) and the values of the owner/manager. The most recent development in ITC is the use of the internet.

The driving factors behind owner/ managers adoption of IT appears to be the need to take control of the financial management coupled with improved accounting software and more powerful hardware systems. Small business financial management has improved since the widespread embracement of computerised accounting software (Breen, Sciulli et al. 2003).

Breen, Sciulli et al. (2003) state that the major benefits of implementing computerised accounting systems are to make execution of business processes more efficient and timely and it takes control of financial management. Burgess (1997) in his study reported the two top ranked benefits as increased efficiency and better access to information. Breen, Sciulli et al. (2003) argued that these benefits would represent time and cost savings for small business and therefore make the cost of accounting software affordable for small businesses.

\section{E-Business}

E-business is a term used to describe business activities and processes conducted on the internet. Zwass (1994) described it the sharing of business information, maintaining business relationships and conducting business transitions by means of internet-based technology. More recently electronic commerce has been identified with a whole business strategy (Lawson, Alcock et al. 2003) that offers a range of services and opportunities including data exchange, mobile telephone, internet, intranet, and email (Quayle 2002). In the context of this study it specifically refers to two way interactive access by accountants with their small business clients. This mode of communication would enable ongoing monitoring of the small businesses and their performance and the provision of management accounting services to the businesses.

Several researchers have identified the opportunities offered by e-commerce to small firms. They include the ability to reduce transaction costs, the development of a more level playing field with larger firms, improved communications, the ability to identify and extend marketing efforts, new markets, cost reduction and developing relations with suppliers (Evans and Wurster 1997). Among the issues that need to be considered include the opportunities and benefits which e-commerce offers, the resources needed, the barriers that must be overcome and the management of risk.

Other studies have shown that firm size, degree of exporting, awareness of benefits and customer type appear to dictate how ICT strategies develop in small firms (Lauder and Westall 1997) and yet others refer to factors which inhibit adoption such as the limited resources of personnel, finance and business knowledge of the small firm compared with its larger counterparts (Simmons, Armstrong et al. 2008). A relationship between size of the business and level of adoption of information technology has also been reported.

Not least is perception of its benefits. Often this means that the competency, knowledge and willingness of the owner/mangers are the deciding factor in the adoption of new technology (Ramsey, Ibbotson et al. 2003).

In addition to these internal factors which influence the adoption of new ITC, external mechanisms have also been found to have an influence. Among these are specific industry and sectoral factors, competitiveness, globalisation, and the growth of a firm in international markets. 
The internet is considered an extremely efficient means of accessing, organising and communication of information, (Peterson, Balasubramanian et al. 1997). Internet reporting has the advantage of the distribution of financial information at a low cost; the ability to provide real-time financial reporting to support internal decision making; and companies that can track financial performance quickly are in a position to discuss any events in an intelligent frank and timely manner when bad news strikes suddenly (Berk 2001).

However, recent research shows that adoption rates of Internet Business Solutions (IBS) are significantly lower for SMEs than for other larger organisations in US and EU. This has led to concern among policy makers that SMEs lag behind the larger firms in adoption of wealth creating technologies and adversely affect their economic performance. The scope of this study is restricted to the investigation of communication via the web between accountants and small business using the internet. The research questions were:

- What use do small businesses currently make of ICT?

- What are some of the new opportunities offered by ICT to accountants and small businesses?

- What are the barriers to the use of new technology?

- What are the benefits to accountants and their small business clients?

\section{Methodology}

This was an exploratory research study that uses quantitative and qualitative methods, which are appropriate for an exploratory study. The study was conducted using in-depth interviews using a structured interview schedule. The qualitative method of content analysis of comments and other qualitative responses and quantitative analysis to obtain descriptive statistics enables the researcher to understand and explain in detail the responsibilities, personal experiences and focus on people's understanding and interpretation rather than seeking external causes or laws for behaviour. This also allows the researcher to report research issues from a participant's perspective.

The survey was conducted using questionnaires which included closed and open-ended questions which gave respondents opportunities to provide comments and raise issues that would be of benefit to the study.

The total sample was 31 respondents comprised of accountants and their small business clients. The sample of accountants was obtained through the National Institute of Accountants who sent an invitation to their Victorian members inviting volunteers to participate in the study. Twenty two accountants responded. The accountants were then asked to contact small business clients who were the owners/managers of small businesses and invite them to participate. Nine SMEs responded. Both accountants and small business owner/managers participated in a one hour interview using a semistructured interview schedule which collected both quantitative and qualitative data. Data were analysed using SPSS for descriptive statistics of the quantitative measures and by content analysis of the qualitative data. The perceptions of the accountants are reported in the tables as frequencies and percentages

\section{Results}

\section{The sample}

Of the sample of accountants, $82 \%$ were male and $18 \%$ female. Over half $55 \%$ had postgraduate qualifications and three quarters $(86 \%)$ had over 11 years experience. Two thirds $(69 \%)$ were located within the Melbourne CBD or suburbs and one third (32\%) in regional Victoria. All except one reported that over $20 \%$ of their clients were small businesses.

Seven of the small business respondents were male and two female. They operated in a range of industries: manufacturing (2) Building (2) bookkeeping (2), and financial services, IT and hospitality (1 in each). Two thirds (7) had less than 20 employees and two employed less than 50 employees. 


\section{What use is currently made of ICT?}

The Study canvassed the perceptions of both accountants and small business use of the internet.

\section{The Accountants}

The most frequently used IT systems (Table 1) by accountancy firms were MYOB (by $100 \%$ ) Excel ((79\%), QuickBooks (/quicken) (50^), BankLink (21\%).

The majority of Accountants in this sample $(\mathrm{n}=17 ; 77 \%)$ reported that their firm had a website. However, many spontaneously commented along the following lines:

- These days, it is a market expectation that Accounting firms have a website and that having a website (somehow) demonstrates that the firm is properly established/ legitimate.

- While the firm's website had been established primarily for marketing/ advertising purposes $(n=14)$, little, if any, business had been generated from the site.

- The website delivered little value to the Accounting firm other than acting as a source of contact information for (a small number of) clients.

- The exceptions were one accounting firm that provided a client portal service on its web site and another that provided educational tools on its site.

- “\$10,000 spent and no response." (Accountant)

Electronic lodgement of Government returns (Taxation, BAS, Payroll tax, ASIC returns, WorkCover, etc) was widespread. All but one of the 20 Accountants, who prepared taxation returns and other government returns for SME clients, reported lodging such returns online.

Only one SME respondent (an Accounting business) prepared their own tax return. In most cases $(n=8)$ the return was prepared by an Accountant and lodged online $(n=7)$.

Respondents were asked about servicing interstate and overseas clients. Seventeen $(77 \%)$ of the Accountant respondents had IT systems (remote access to their office server and mobile email and Internet access). A few also had remote access to their clients' networks.

However, only one serviced overseas clients. In this case, it was a trust run out of London with much of the communication being via Skype. It was pointed out that most Australian accountants have no standing to provide accounting services overseas.

Table 1: Current IT Usage - Accountants

\begin{tabular}{|l|l|l|l|}
\hline IT Usage & Number (n) & $\begin{array}{l}\text { Percentage of } \\
\text { responses (\%) }\end{array}$ & $\begin{array}{l}\text { Percentage of } \\
\text { respondents (\%) }\end{array}$ \\
\hline Accounting software & 14 & $26 \%$ & $70 \%$ \\
\hline Office software applications & 9 & $17 \%$ & $45 \%$ \\
\hline Internet applications & 7 & $13 \%$ & $35 \%$ \\
\hline Online access to Government (ATO, ASIC) and other agencies & 7 & $13 \%$ & $35 \%$ \\
\hline Data transmission & 4 & $8 \%$ & $20 \%$ \\
\hline Intranet applications & 2 & $4 \%$ & $10 \%$ \\
\hline Remote access to client data & 2 & $4 \%$ & $10 \%$ \\
\hline Remote access to office systems & 2 & $4 \%$ & $10 \%$ \\
\hline Mobile communications (e.g. email, diary via i-Phone) & 2 & $4 \%$ & $10 \%$ \\
\hline Management of client and supplier databases & 1 & $2 \%$ & $5 \%$ \\
\hline Timing and costing of work units & 1 & $2 \%$ & $5 \%$ \\
\hline e-Commerce & 1 & $2 \%$ & $5 \%$ \\
\hline Continuing Professional Education & 1 & $2 \%$ & $5 \%$ \\
\hline
\end{tabular}

The main way in which accountants transferred data to their clients was via email (905) but paper was still important (75\%). Disk, fax and memory sticks were also used. The results confirm previous findings in a study conducted by Poon and Swatman (1997) who also report email as a main form of communication with customers. 


\section{Small business}

All the businesses used IT packages. As one said:

We use it for everything - client control, financial plans, receiving and transmitting information, liaising, making appointments, on-line training, etc." (SME)

Eight of the nine SME respondents had a business web site which was used as follows:

- Marketing information for customers and potential employees (7 mentions);

- Provision of contact information (2);

- Educational tool (reference information for technicians who use the company's products, an electronic newsletter) (2);

- Facility for clients to lodge a request for a quote (2).

\section{What are the barriers to the use of new technology?}

Fourteen (64\%) respondent Accountants and four SME nominated factors that could or would deter Accountants from using a continuous online monitoring and access system with their SME clients. However, the most frequently reported reasons (Tables 2 and 3), were cost and compatibility with other systems.

Three Accountants respondents rejected the possibility of adopting a new interactive system entirely; maintaining that they had no need for such a system and did not perceive any benefits from using it.

Table 2: Barriers to Adoption by Accountants

\begin{tabular}{|l|l|l|l|}
\hline Barrier & Accountant Sample \\
\hline & Number (n) & Percentage of responses (\%) & $\begin{array}{l}\text { Percentage of } \\
\text { respondents (\%) }\end{array}$ \\
\hline Cost & 8 & $38 \%$ & $57 \%$ \\
\hline Concerns about security/privacy of data & 3 & $14 \%$ & $21 \%$ \\
\hline Unauthorised access to the data & - & - & - \\
\hline No need; no perceived benefits & 3 & $14 \%$ & $21 \%$ \\
\hline $\begin{array}{l}\text { Time required to set up and integrate with } \\
\text { other systems }\end{array}$ & 2 & $10 \%$ & $14 \%$ \\
\hline Implementation and maintenance issues & 2 & $10 \%$ & $14 \%$ \\
\hline Poor Internet service in regional areas & 1 & $5 \%$ & $7 \%$ \\
\hline Accountant's liability & 1 & $5 \%$ & $7 \%$ \\
\hline Lack of expertise/need for training & 1 & $5 \%$ & $7 \%$ \\
\hline
\end{tabular}

Sixteen (73\%) Accountants and seven SMEs nominated factors that could or would deter SMEs from using a continuous online monitoring and access system.

A third of the Accountant respondents noted that at least some SMEs would not have the resources (time, computer equipment, IT knowledge and training) required to establish and maintain such a system. 
Table 3: Barriers to Adoption by SMEs

\begin{tabular}{|l|l|l|l|}
\hline Barrier & \multicolumn{3}{l|}{ Accountant Sample } \\
\hline & Number (n) & $\begin{array}{l}\text { Percentage of } \\
\text { responses (\%) }\end{array}$ & $\begin{array}{l}\text { Percentage of respondents } \\
(\%)\end{array}$ \\
\hline Lack of expertise & 8 & $27 \%$ & $50 \%$ \\
\hline Cost & 7 & $23 \%$ & $49 \%$ \\
\hline Privacy concerns & 5 & $17 \%$ & $31 \%$ \\
\hline Time required to set up and manage & 3 & $10 \%$ & $19 \%$ \\
\hline Incompatibility with other systems & 2 & $7 \%$ & $13 \%$ \\
\hline Poor Internet service in regional areas & 2 & $7 \%$ & $13 \%$ \\
\hline $\begin{array}{l}\text { No need (e.g. does not fit with SME monthly reporting } \\
\text { cycle); no benefit }\end{array}$ & 1 & $3 \%$ & $6 \%$ \\
\hline Access to information & 1 & $3 \%$ & $6 \%$ \\
\hline Glitches with new software programs & 1 & $3 \%$ & $6 \%$ \\
\hline
\end{tabular}

Some opinions were:

"The client must accept that the accountant will make a valid contribution. Many are protective or defensive about advice in helping the business." (Accountant)

"Hacking [would be a concern]. We would need to be confident about the data security... It might be incompatible with IT systems for example, if the client has old systems.... And, all new systems have glitches.... I already do a lot of the record keeping for them [small business clients] for example, minutes of meetings. Therefore the client may see the new system as 'more work for me'. They may prefer that the accountant still does this." (Accountant)

Just under half of both the Accountant $(\mathrm{n}=10 ; 46 \%)$ and SME sample $(\mathrm{n}=4)$ had concerns about privacy, confidentiality and/or security. The suggestions of seventeen Accountant respondents (77\%) and eight SMEs to address concerns about privacy, security and/or confidentiality, a back up/disaster recovery facility, codes of conduct, Secure IP address, and firewalls.

Table 4: Concerns re Privacy, Security\& Confidentiality

\begin{tabular}{|l|l|l|l|}
\hline Barrier & $\begin{array}{l}\text { Number } \\
\text { Accountants ( } n)\end{array}$ & $\begin{array}{l}\text { Number } \\
\text { SMEs (n) }\end{array}$ \\
\cline { 1 - 2 } & & 4 \\
\cline { 1 - 2 } $\begin{array}{l}\text { The risk of hacking } \\
\text { party information) }\end{array}$ & 4 & 2 \\
\hline Confidentiality & 3 & - \\
\hline Compliance with the Privacy Act & 2 & - \\
\hline Restrictions regarding the disclosure of Tax File Numbers & 1 & - \\
\hline Viruses & 1 & - \\
\hline Liability for data integrity & 1 & - \\
\hline
\end{tabular}

(Sample bases: 10 Accountants and 4 SMEs who nominated concerns)

\section{What are the benefits to accountants and their small business clients of web based ITC?}

The following table 5 summarise the likely benefits of a continuous online monitoring and access system for Accountants, SME clients, and the Government, respectively.

Some benefits seen by accountants were that it could prove time saving, offer better service, and information. As they said:

"This could be good for some of the big clients; those with over \$10M turnover ... It would generate fees and cement the relationship." (Accountant) 
"The concept of having a 'window to the business' is good. Automated reporting could be an add-on option, but it would have to be sophisticated and tailored to the particular business." (Accountant)

"Like BankLink where you can get the clients' bank statements and can code it." (Accountant)

"Time saving ... real time information ... more accurate and up-to-date information and we don't have to rely on the client providing all the information needed (often it comes in drips and drabs)." (Accountant)

"It's management by exception, which I like. I like the monitoring system... The benefit over others [packages] is that the accountant has [continual] access to it [the client's data] .... MYOB has something similar but I've not had much luck with it. It must be easy to use and easy to export data." (Accountant)

"Improved service and less paper-based services." (Accountant)

"Increased income and profit... Enhanced advisory services." (Accountant)

Not all the views were positive:

"I don't see any benefit. I don't need on-going real time access to client information. I deal with clients, event by event." (Accountant)

"Most are very small and in control and know what funds they have... Most don't seek financial advice about the business performance and some are shy - their information is private." (Accountant)

\section{Table 5: Benefits for Accountants}

(Sample bases: 20 Accountants and 8 SMEs who perceived benefits for Accountants)

\begin{tabular}{|l|l|l|l|}
\hline Benefit & Accountant Sample & \multicolumn{2}{l|}{} \\
\hline & Number (n) & $\begin{array}{l}\text { Percentage of } \\
\text { responses (\%) }\end{array}$ & $\begin{array}{l}\text { Percentage of } \\
\text { respondents (\%) }\end{array}$ \\
\hline Enhanced client service & 14 & $14 \%$ & $70 \%$ \\
\hline Fast client notification of problems & 13 & $13 \%$ & $65 \%$ \\
\hline Direct communication with client & 11 & $11 \%$ & $55 \%$ \\
\hline Ability to identify clients' impending financial problems & 11 & $11 \%$ & $55 \%$ \\
\hline Reduced cost (to client) & 10 & $10 \%$ & $50 \%$ \\
\hline The potential for proactive offers of new services & 10 & $10 \%$ & $50 \%$ \\
\hline Efficiency and productivity gains & 8 & $8 \%$ & $40 \%$ \\
\hline Improved client relationship & 8 & $8 \%$ & $40 \%$ \\
\hline Save time & 6 & $6 \%$ & $30 \%$ \\
\hline Easy access to client data; convenience & 4 & $4 \%$ & $20 \%$ \\
\hline Facility to monitor client KPIs & 1 & $1 \%$ & $5 \%$ \\
\hline $\begin{array}{l}\text { Accountant access to more accurate, up-to-date, real- } \\
\text { time data }\end{array}$ & 1 & $1 \%$ & $5 \%$ \\
\hline Better understanding of the business' activity & - & - & - \\
\hline Opportunity to generate more fees & - & - & - \\
\hline
\end{tabular}

The business respondents identified the practical advantages (Table 6) of having ease of transfer of information and increased efficiency:

"He could access our information whenever; he wouldn't need to visit and back up our $M Y O B$ files [which are too large to email and so have to be put on disk] ... It's an accessibility benefit - they can access the data whenever they want - after hours, on the weekend, if I'm away..." (SME)

"[The benefits would be] streamlined operations, easy access, automated, remote access, efficiency." (SME) 
Table 6: Benefits for SMEs

(Sample bases: 20 Accountants who perceived some benefits for SMEs; 6 SMEs who perceived some benefits for their respective business)

\begin{tabular}{|l|l|l|l|}
\hline Benefit & Accountant Sample & \multicolumn{2}{l|}{} \\
\hline & Number (n) & $\begin{array}{l}\text { Percentage of } \\
\text { responses (\%) }\end{array}$ & $\begin{array}{l}\text { Percentage of } \\
\text { respondents (\%) }\end{array}$ \\
\hline Fast notification of impending problems & 11 & $15 \%$ & $55 \%$ \\
\hline Reduced service response time & 11 & $15 \%$ & $55 \%$ \\
\hline The ability to respond quickly to orders, tenders, etc & 10 & $14 \%$ & $50 \%$ \\
\hline Direct communication & 9 & $13 \%$ & $45 \%$ \\
\hline Reduced cost & 9 & $13 \%$ & $45 \%$ \\
\hline Quicker budget projections & 6 & $8 \%$ & $30 \%$ \\
\hline Would help identify profit drivers of business & 5 & $7 \%$ & $25 \%$ \\
\hline Better quality/more data/up to date data & 4 & $6 \%$ & $20 \%$ \\
\hline Ready access to information (faster decision making) & 4 & $6 \%$ & $20 \%$ \\
\hline Save time & 2 & $3 \%$ & $10 \%$ \\
\hline Minimise amount of work required by client & 1 & $1 \%$ & $5 \%$ \\
\hline Reduced administration & - & - & - \\
\hline Facility to automate government returns & - & - & - \\
\hline
\end{tabular}

In regard to a continuous system that could be accessed by government, both Accountants and SME respondents raised concerns that the Government might have access to SME files in their system.

Some small businesses thought that there were advantages:

"The information would be more accurate and so there'd be fewer problems with people understating their income [to the ATO], etc." (Accountant)

"This fits with automated BAS, tax and super returns, which is OK. But, many would not want to, say, flag to the regulator that their earnings had gone up in a quarter." (Accountant)

"It could not be linked to government. Clients are very nervous about government/ATO getting their details - Big Brother." (Accountant)

But there were reservations:

"It's $O K$ if it's between the accountant and us ... But we don't want ATO having access. For example, if we put something [an entry] in the wrong place, we need the opportunity to correct it." (SME)

Table 7: Benefits for Government Regulators

\begin{tabular}{|l|l|l|l|l|l|}
\hline Benefit & \multicolumn{2}{|l|}{ Accountant Sample } & SME Sample \\
\cline { 1 - 4 } & Number (n) & $\begin{array}{l}\text { Percentage of } \\
\text { responses (\%) }\end{array}$ & $\begin{array}{l}\text { Percentage of } \\
\text { respondents (\%) }\end{array}$ & Number (n) \\
\cline { 1 - 3 } & 5 & $30 \%$ & $39 \%$ & 4 \\
\cline { 1 - 3 } $\begin{array}{l}\text { More accurate data } \\
\text { deadlines }\end{array}$ & 4 & $24 \%$ & $31 \%$ & 2 \\
\hline Faster lodgement of returns & 1 & 1 & 1 & 3 \\
\hline Increased compliance (e.g. re GST) & 2 & $12 \%$ & $8 \%$ & 1 \\
\hline $\begin{array}{l}\text { Less time required for SMEs to prepare } \\
\text { returns }\end{array}$ & 1 & $6 \%$ & $8 \%$ & 1 \\
\hline $\begin{array}{l}\text { Fits with Government plan to drive } \\
\text { eBusiness }\end{array}$ & 1 & $6 \%$ & 1 \\
\hline
\end{tabular}

(Sample bases: 9 Accountants and 6 SMEs who perceived benefits for government)

While the majority of Accountants in this study did not perceive any direct or flow-on benefits that a continuous online monitoring and access system would deliver to Government regulators, six of the nine SME respondents were able to nominate at least one benefit for government regulators. 


\section{What are some of the new opportunities offered by ICT to accountants?}

The study explored the perceptions of the usefulness of a continuous online communication system between accountants and small business clients which, would include various reporting facilities and have a trouble-shooting facility whereby both parties would be alerted should any pre-programmed criteria be met (e.g. evidence of an impending cash flow problem).

The majority of Accountants in this study (80\%) thought such a system would be useful or very useful for (at least some) SME clients and for Accountants who service SMEs (81\%). As one said "An early problem detection system would be useful".

Some reservations expressed by small business were that it would be "not useful... too much information; don't want to give the accountant access to all that... Over-engineering...No need" and "we would have to pay more for this..." Others were more positive. SMEs appraised the system as having greater utility for Accountants than for SMEs: 67\% of SMEs thought such a system would be useful or very useful for their business; $86 \%$ thought it would be useful or very useful for Accountants.

\section{Conclusion}

The purpose of this paper was to determine the potential for the adoption by small business and accountants of new technology such as interactive ICT. The investigation selected the interaction of small businesses with their accountants, the most used consultant by small business, to research the issue. The opinions of both groups were necessary as one could not act without the compliance of the other.

The review of the literature identified a number of factors which could inhibit the adoption of ICT by small business. In this study similar results were found. Cost, lack of time, skills and knowledge were uppermost. Small business may have the capacity to respond quickly to new innovations but both accountants and small business respondents expressed reservations about the adoption of interactive ICT. Among the barriers to adoption were cost, compatibility with existing systems and privacy issues.

The limitations of the study were the small sample size. Although the sample size was small, accountants were distributed across regional and metropolitan areas, and they included a range of gender, age and qualifications. Because it was a 'volunteer' group it may be biased towards those with higher levels of qualifications and interests in adopting newer information technology. The diversity of small business industries represented by their clients suggests that their views could be representative of the sector. However, their very diversity means that the internal firm mechanisms identified in the study as having an impact on perceptions of the innovation may differ if the types of business and their specific use of "ICT were taken into account. This could only be done by further research with a much larger sample.

\section{References}

Australian Corporations and Securities Legislation (2009). Australian Corporations and Securities Legislation,.

Berk, J. (2001). “Leveraging the Internet for Financial Reporting.” Financial Executive 17(3): 54-56.

Birch, D. (1987). Job Creation in America: How our smallest companies put the most people to work. New York, Free Press.

Breen, J., N. Sciulli, et al. (2003). The Role of External Accountant in Small Firms. 16th Annual Conference of Small Enterprise Association of Australia and New Zealand. University of Ballarat.

Burgess, S. (1997). “A Categorised Study of the Use of IT in Small Business" Detailed Survey Report. Melbourne, Australia, Small Business Victoria.

Burgess, S. (2002). Managing Information Technology in Small Business: Challenges and Solutions. Hershey, PA, Idea Group Publishing. 
Burgess, S. and R. Hill (2004). Corporate Governance in Small Business. Applications of Corporate Governance. A. Armstrong and R. Francis. Sydney, Standards Australia International Ltd. HB4012004.

Burgess, S. and D. Schauder (2003). Small business e-commerce research:an interpretivist approach? Australia, Heidelberg Press. Clarke, T. and A. Kettner (2009 in press). "Governance Issues for SMEs." Journal of Business Systems Governance and Ethics.

Doern, R. (2009). "Investigating Barriers to SME Growth and Development in Transition Environments." International Small Business Journal 27(3): 275-305.

Evans, P. B. and B. S. Wurster (1997). "Strategy and the New Economics of Information." Harvard Business Review 75(5): 70-83.

Festervand, T. A. and J. Forrest (1991). Small Business Failures: A Framework for Analysis. Proceedings of the Small Business Institute Director's Association Conference. Orlando, FL: 1-14.

Fillis Ian and Wagner Beverly (2005). "E-business Development.” International Small Business Journal 23(6): 604-634.

Francis, R. and A. Armstrong, Eds. (2006). Governance in Small Business. Sydney, Standards Australia International

Gallagher, C. C. and P. Miller (1991). "New Fast-Growing Comopanies Creat Jobs." Journal of Enterprise Culture 8: 321-42.

Lauder, G. and A. Westall (1997). "Small Firms Online." Commission on Public Policy on British Business 6.

Lawson, R., C. Alcock, et al. (2003). "Factors affecting adoption of electronic commerce technologies by SMEs: an Australian study." Journal of Small Business and Enterprise Development 10(3): 265276.

Navarro, M. S. and S. G. Anson (2009). "Do Families Shape Corporate Governance Structures?" Journal of Management and Organizations 15(3): 327-345.

Peterson, R. A., S. Balasubramanian, et al. (1997). "Exploring the Implications of the Internet for Consumer Marketing.” Journal of the Academy of Marketing Science 25(4): 329-346.

Poon, S. and P. M. C. Swatman (1997). "Small Business Use of the Internet: Findings from Australian Case Studies." International Marketing Review 14(5): 385-402.

Quayle, M. (2002). "E-Commerce: The Challenge for UK SMEs in the Twenty-First Century." International Journal of Operations and Production Management 22(10): 1148-1161.

Ramsey, E., P. Ibbotson, et al. (2003). "E-Opportunities of Service Sector SMEs: An Irish CrossBorder Study." Journal of Small Business and Enterprise Development 10(3): 250-264.

Simmons, G., G. A. Armstrong, et al. (2008). "A Conceptualization of the Determinants of Small Business Website Adoption.” International Small Business Journal 26(3): 351-389.

Watson, J. and J. E. Everett (1996). "Do Small Business Have High Failure Rates: Evidence from Australian Retailers.” Journal of Small Business Management(October): 45-62.

Zwass, V. (1994). "Electronic Commerce: Structures and Issues." International Journal of Electronic Commerce 1(1): 3-23. 